\title{
Design-Build Approaches with Building's Users in Local School Case Study in Cairo, Egypt
}

\author{
Ibrahim Samy Sayed Saleh ${ }^{1, *}$, Mostafa Refaat Ahmed Ismail ${ }^{2}$, Ahmed Atef Eldesouky Faggal², \\ Alaa Adel Mahmoud Al-shareef ${ }^{3}$ \\ ${ }^{1}$ Architecture and Urban Design Program, German University in Cairo, 11511, Cairo, Egypt \\ ${ }^{2}$ Department of Architectural Engineering, Ain Shams University, 11566, Cairo, Egypt \\ ${ }^{3}$ Department of Architectural Engineering, Cairo University, 12613, Cairo, Egypt
}

Received November 1, 2020; Revised March 21, 2021; Accepted April 9, 2021

\section{Cite This Paper in the following Citation Styles}

(a): [1] Ibrahim Samy Sayed Saleh, Mostafa Refaat Ahmed Ismail, Ahmed Atef Eldesouky Faggal, Alaa Adel Mahmoud Al-shareef , "Design-Build Approaches with Building's Users in Local School Case Study in Cairo, Egypt," Civil Engineering and Architecture, Vol. 9, No. 3, pp. 828-835, 2021. DOI: 10.13189/cea.2021.090324.

(b): Ibrahim Samy Sayed Saleh, Mostafa Refaat Ahmed Ismail, Ahmed Atef Eldesouky Faggal, Alaa Adel Mahmoud Al-shareef (2021). Design-Build Approaches with Building's Users in Local School Case Study in Cairo, Egypt. Civil Engineering and Architecture, 9(3), 828-835. DOI: 10.13189/cea.2021.090324.

Copyright $(2021$ by authors, all rights reserved. Authors agree that this article remains permanently open access under the terms of the Creative Commons Attribution License 4.0 International License

\begin{abstract}
A design build studio approach is a design process that involves the users, local community, and professionals in the entire development of a project - from the conceptual ideas generation to the implementation phase. This paper aims at analyzing techniques of involving the school students directly in the process of improving their school built elements performance - with focus on social spaces such as playgrounds - from the design and planning phases to the implementation phase. The main goal is to develop a model to involve the students in the process of realization, which includes not only the satisfaction achieved at the end, but also the problems, difficulties, and compromises that have to be faced in the process. The case study for testing the design - build techniques with building's users and local community is Shagaret el Dorr School in Ibn Tulun district. The paper will test the efficiency of physical model technique for filtering and analyzing the spatial qualities and intended activities from the children's models and eventually transform these collected data and user's input into design proposals to be built. A survey was done to assess the process and results of the case study and sent to project's participants and professional architects. The results of the survey will be part of holistic criteria for school design participatory process. The end result will be a matrix of design build techniques and guidelines for working with users and community (phase 01 ), transferring into designs (phase 02), and building (phase 03).
\end{abstract}

Keywords Design-Build, Playgrounds, School Architecture, Community Based Design, Techniques of Participation

\section{Introduction}

Design and Build approach is student and professional team participatory design process - from first idea, through discussions, to direct execution. Students are directly involved in the design process - from the conceptual design to the implementation phases [1]. This model is a counterpart to the standardized school design as part of the mass construction of schools that began in the 1980s and still many of the current schools worldwide and in Egypt were constructed around this period [2].

Shajarat Al-Durr Primary School is located in a rich historical area inside Islamic Cairo. The school is located directly in front of the Ibn Tulun Mosque, near the Sergmatic Mosque and the House of Kurtilia. The existing housing units are mixture of old residential buildings and new buildings (mostly random informal housing units within the historical context) with many small workshops for wood, glass, fabric, iron ... etc. Most of the residents of this neighborhood are low-income residents (with some middle income also; like workshop owners, local building 
material suppliers, small contractors ... etc).

The school is a standard public school model with the main school building consisting of four floors and single loaded corridors with classrooms facing the schoolyard, and corridors facing the back garden. The courtyard is used as a gathering space for students (more than 300 students) and as a playground without any furniture.

\section{Working with School's Children}

A proposal was done to do a participatory design-build studio with architecture students from Egypt and Germany with children and teachers from Shagaret el Dorr School. After discussions with school administration and teachers, the playground area was selected to be the main design space of the workshop as it lacked any furniture or outdoor play elements that the school's students needed. The project took place in 2014 and the title of it was Learn-Move-Play-Ground - LMPG under supervision of Barbara Pampe and Vittoria Capresi.

The participatory strategy included working with twenty children, a team of teachers, and professionals (including professors and students from Siegen University in Germany) was included in order to work more effectively with school teachers. The materials provided to the children for the collage were more physical than abstract pictures as shown in figure 01 .

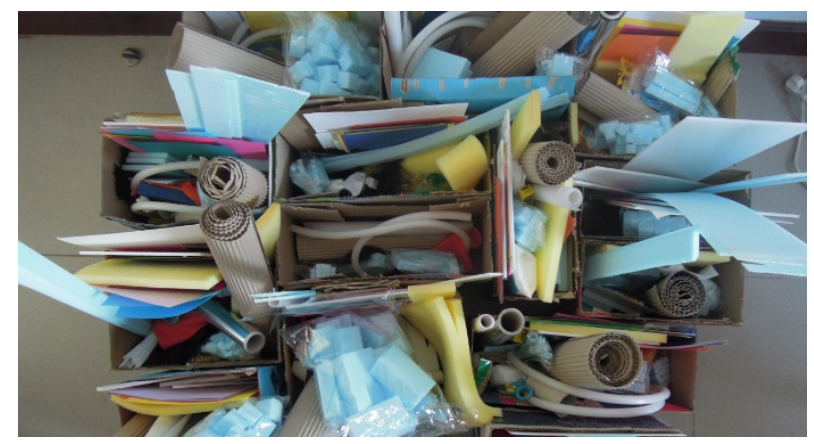

Figure 1. Sample of the Materials Provided for the Children. Photos: LMPG2 Team, 2014

\subsection{Children Workshop}

The team was divided into groups; each group has Germans and Egyptians (Architects, Landscape Architects, and Pedagogue) and each group was responsible for one or two children.

Children were asked to create the playground of their dreams, a space in which they could spend their dream day that should not be confined to school. The kids started telling the teams their memory / vision of their best day or dream day. Some told stories of a day at the park with the family, a football match, a day at the beach, etc.

The small teams carefully listened to children/students' stories and started helping children transform these stories
/ dreams into physical complexes with spatial attributes. Children were provided with various physical materials such as; Foam, papers of various colors and combinations, plastic sheets, cardboard, cloth, foil ... etc.

The use of physical modeling technology made it easy for the professionals' team to filter and analyze the spatial characteristics and intended activities of the children's models. The use of physical materials also gave children the opportunity to stimulate their senses of touch, and to choose materials with a soft, hard or smooth surface, etc.

From another point of view, model making materials limited their representation / transformation of children's dream day to models, as it was restricted to a variety of materials, in contrast to abstract images which offered a wider range of imagination / interpretations.

The children were asked to name their models, and they began showing their work to all of the other participants; they began by telling their story and how they envision themselves occupying and using the space they created in their models as illustrated in figure 02 .

Most of the children had a logical space (soccer field, seating area, walls, house, beach ... etc.) within their models and added creative ideas to it. During the presentation to the children, they also mentioned with those who want to share their dream day, and they explained / imagined how the people who choose to join them will behave and use their daily dream model / space. Previous data were important to further understanding the personality and needs of each child, and how they can be transformed into actual, built-in elements in their schoolyard.

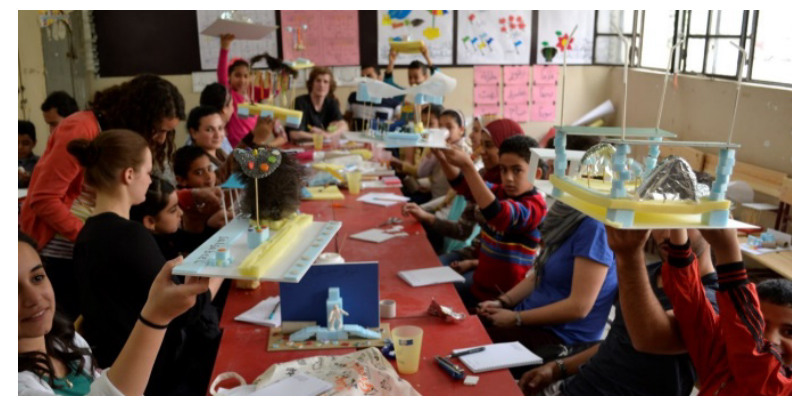

Figure 2. Children Presentation in Shagart El Dorr School. Photos: Author, 2014

\section{Transferring into Designs}

After the presentations, the professionals' team in the school put together all the physical models that the children made and began jotting their impressions, brainstorming the ideas, and how the team can transform the children's dreams into a physical environment / playground.

The first step was to convert their stories into physical actions using simple keywords such as: back down, watch, climb, relax, hide, fly, jump, rest, gather, sit, chat, slide, 
snuggle, feel, chill ... etc.

The second step was to create groups of keywords that could work together in order to start working on how to turn each group into play and learn elements built into the schoolyard.

The keywords were associated with school's yard, based on team feedback and input from the teachers' workshop. Various design proposals have been made that express different spatial characteristics and different experiences such as; Discovery, exploration, conquest, dark spaces / caveman, switching, private space, anticipation, observation / setting above, waiting, diversity, cross-chain ... etc.

These qualities and experiences illustrated in the models are explained and realized by describing procedures within spatial designs such as; Sit above or below it, hide under or behind it, climb up and down, jump ... etc.

The spatial models proposals investigated the effects of different materials (glossy, transparent, reflective ... etc.), the effect of different colours, and various spatial properties / alternatives (container within a space, repeating elements, vertical, horizontal, elemental scale, linear, central, curved. ... etc), the shade and shadow patterns within proposals, and how these elements relate to data / keywords that have been adapted from the previous stages.

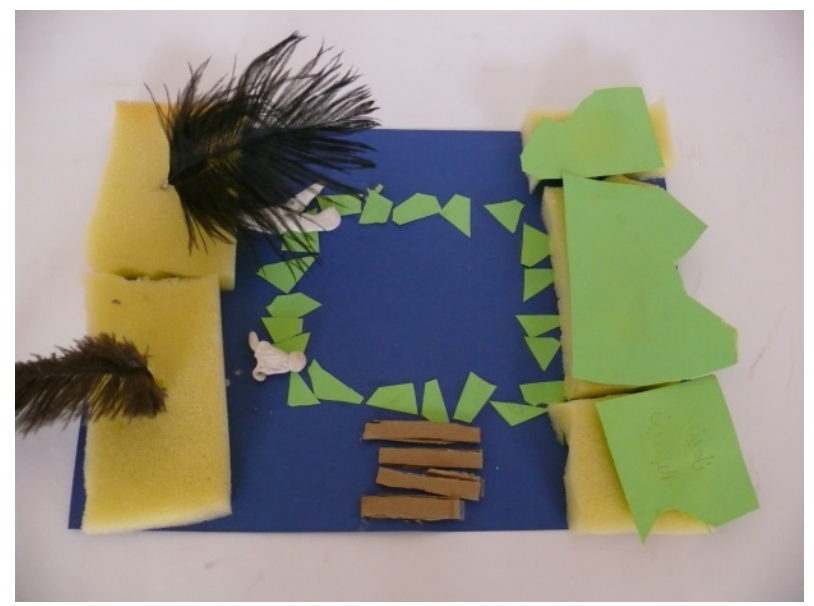

Figure 3. Sample of the Children Models. Photos: LMPG2 Team, 2014

\section{Design within the School Setting}

Each group was asked to develop a common idea / proposal corresponding to the site chosen for implementation. Specific locations were determined based on team discussions and teachers' input that was summarized in diagrams and notes on school's layout drawing. Safety measures were taken into consideration when selecting applications (such as playground material: soft / sandy materials are suitable for running, climbing and jumping, and hard materials such as tiles or concrete floors are more suitable for high / lower risk activities such as sitting, chatting or hiding). The new planting should also take into account the available building materials (brick, cement, sand, gravel and wood in both schools).

The playground was divided in different zones (as per figure 04); zone 01 the assembly area, zone 02 entrance, zone 03 non-used area next to school fence/wall, and zone 04 the back garden. Teams worked on developing design proposals in the different zones; in the area between the soccer area and the school's perimeter wall. The proposals included an outdoor seating area and elements for running, jumping, sliding and watching by the football field.

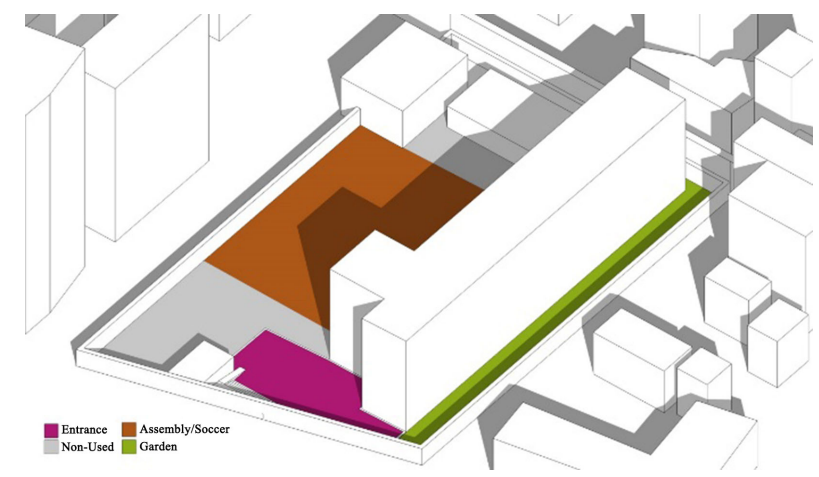

Figure 4. Shagret El Dorr School Cortyard Activities/Functions Distribution. Author, 2020

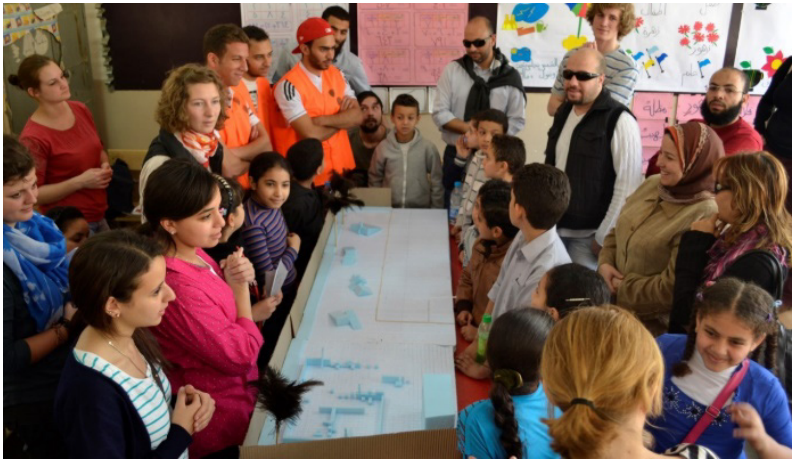

Figure 5. Children \& Teachers Presentation/Feedback (Photos: Author, 2014)

\section{Finalizing Designs/ Building}

Teams submitted design proposals to school teachers, headmaster and children. The design methodology and the process of converting "Dream Day" models into design proposals were explained. Design ideas were presented using physical models of intended executed objects and physical school model. The school physical model made it easy to explain the ideas to children and teachers as well. After feedback from children and teachers, the design teams were asked to start making final adjustments and start developing building and structural proposals for their designs. In the final design phase, durability and safety 
measures must be taken into account, and the effect of the permissible time frame for construction (three days) on the final design results (in size and quantity of the proposed objects), with - once again - careful consideration of safety and shading measurements. Children participated in the construction phase as well in order to create a kind of personal ownership and commitment.

One of the main goals was to involve the local community in the participatory process; based on this approach, the brick workers were from the school's district, and the building material suppliers were also from the school's district (as illustrated in figure 06), which helped the community understand and accept the ongoing engagement process.

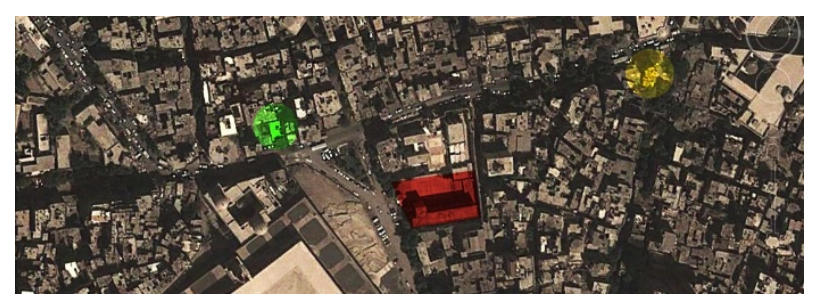

Figure 6. Brick Worker House (Green Circle) \& Construction Material Supplier Location (Yellow Circle) in both Schools. Google Earth edited by Author, 2020

\section{Final Results}

Final design applications included built elements for: Running / Jumping / Sliding / Sitting / Balance next to the football field, Sitting / Chatting / Observation / Brick assembly next to the school entrance / gate room that can be used for watching football matches, climbing / balance beams in the sandy area next to the back garden, which it was decided to add on the site after leaving additional wooden beams.

Running / Jumping / Sliding / Seating Sliders (The sequence of elements was optimized for the linear space between the football field and the school fence / wall).

The different levels in the configuration are inspired by the children's dream day models, and have also been used to provide a comfortable seating position for different ages with different heights.

There was also a discussion about coloring items or leaving red bricks exposed, but after consulting with teachers and the principal, they suggested that it should be painted because school students actually live in red brick homes and encounter these red bricks in most of the urban environment in their daily lives, so add some cheerful colors to the items make them more preferred by the kids.

\section{Guideline Criteria for Participatory School Design}

Table 01 summarizes the steps of the participatory design process with school's children and teachers. The participatory strategy proved to be appropriate for different situations / contexts but on the other hand, the strategy proved that it faces problems with the huge numbers of students. The different methods in the children's workshop stage demonstrated the strengths and weaknesses of each choice; When children were provided with abstract images to create collages, they were free and creative in their collages but it was difficult to convert these very abstract collages into spatial design proposals, on the other hand when children were provided with physical model materials, the results were limited in most cases with the actual physical environment they encounter in their daily lives, but was most efficient when it came to transforming their dream models into a spatial physical model.

Table 1. Criteria for School Participatory Design. Author, 2020

\begin{tabular}{|c|c|c|}
\hline Phase & Title & Strategy / Criteria \\
\hline 01 & Children Workshop & Dream Playground \\
\hline & & Collage Presentation \\
\hline & & Collage Analysis \\
\hline 02 & Teachers Workshop & Activity Diagrams \\
\hline 03 & Transform into Design & Physical Dreams \\
\hline & & School Setting \\
\hline & & Feedback \\
\hline 04 & Building & \\
\hline 05 & Results & \\
\hline
\end{tabular}

A survey was done addressing mainly project's participants to assess the proposed guidelines for the participatory process from the perspective of set of developed criteria elements that was developed before the start of the participatory process. The results of the survey are analysed in the following table 02 . The table explains how to use these guidelines for having structured participatory model techniques/actions, then convert data from these techniques/actions into project-specific guiding standards, and finally use the same criteria to evaluate the project's participatory process and overall results. 
Table 2. Special Guideline Criteria for School Design Based on the Survey. Author, 2020

\begin{tabular}{|c|c|c|c|c|c|c|c|c|c|c|c|c|}
\hline \multirow{2}{*}{ guideline } & \multicolumn{3}{|c|}{ children workshop } & \multirow{2}{*}{ 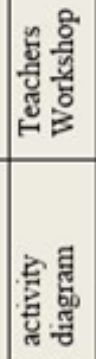 } & \multicolumn{4}{|c|}{ transfer into design } & \multirow[b]{2}{*}{ 哥 } & & \multirow[t]{2}{*}{ criteria } & \multirow{2}{*}{$\begin{array}{l}\text { total } \\
\text { load }\end{array}$} \\
\hline & 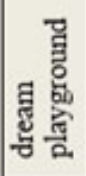 & 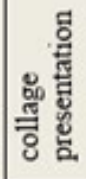 & 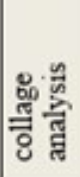 & & 갤 & 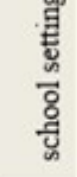 & 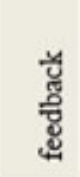 & 哭 & & 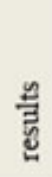 & & \\
\hline \multirow[t]{7}{*}{$\begin{array}{l}\text { participatory } \\
\text { process }\end{array}$} & 3 & 3 & 3 & 2 & 6 & 6 & 3 & 3 & 3 & 1 & prescribed & 33 \\
\hline & 6.67 & 6.67 & 6.67 & 3.33 & 3.33 & 3.33 & 3.33 & 3.33 & 3.33 & 4 & assigned & 43.99 \\
\hline & 8.18 & 8.18 & 8.18 & 2.72 & 1.81 & 1.81 & 2.72 & 2.72 & 2.72 & 8 & invited & 47.04 \\
\hline & 3.33 & 3.33 & 3.33 & 2.22 & 2.22 & 2.22 & 4.44 & 4.44 & 0 & 8 & negotiated & 33.53 \\
\hline & 4 & 4 & 4 & 0 & 0 & 2 & 2 & 2 & 2 & 10 & self-initiated & 30 \\
\hline & 1.67 & 1.67 & 1.67 & 3.33 & 0 & 0 & 5 & 5 & 0 & 10 & graduated & 28.34 \\
\hline & 2 & 2 & 2 & 4 & 2 & 2 & 7 & 7 & 4 & 10 & collaborative & 42 \\
\hline \multirow[t]{3}{*}{$\begin{array}{l}\text { explorative } \\
\text { learning }\end{array}$} & 4.54 & 4.54 & 4.54 & 5.45 & 4.54 & 4.54 & 6.36 & 6.36 & 4.54 & 8 & observation & 53.41 \\
\hline & 5.54 & 5.54 & 5.54 & 5.54 & 3.63 & 3.63 & 7.27 & 7.27 & 3.63 & 8 & exercising & 55.59 \\
\hline & 5.54 & 5.54 & 5.54 & 3.63 & 3.63 & 5.45 & 5.45 & 5.45 & 3.63 & 9 & space research & 52.86 \\
\hline \multirow[t]{2}{*}{$\begin{array}{l}\text { school } \\
\text { curriculums }\end{array}$} & 5.45 & 5.45 & 5.45 & 4.54 & 3.63 & 3.63 & 5.45 & 5.45 & 2.72 & 10 & applied & 51.77 \\
\hline & 2.72 & 2.72 & 2.72 & 5.45 & 6.36 & 6.36 & 5.45 & 5.45 & 4.54 & 10 & $\begin{array}{l}\text { children space } \\
\text { dialogue }\end{array}$ & 51.77 \\
\hline \multirow[t]{3}{*}{$\begin{array}{l}\text { local } \\
\text { environment }\end{array}$} & 5 & 5 & 5 & 5 & 5 & 5 & 4 & 4 & 3 & 10 & outdoor & 51 \\
\hline & 3.36 & 3.36 & 3.36 & 5.54 & 9.09 & 9.09 & 6.36 & 6.36 & 3.63 & 3 & indoor & 53.15 \\
\hline & 10 & 10 & 10 & 5 & 5 & 5 & 6 & 6 & 7 & 10 & adaptive & 74 \\
\hline \multirow[t]{3}{*}{ local culture } & 6.36 & 6.36 & 6.36 & 6.36 & 4.45 & 4.45 & 5.45 & 5.45 & 1.81 & 10 & school role & 57.05 \\
\hline & 4.45 & 4.45 & 4.45 & 7.27 & 6.36 & 6.36 & 5.45 & 5.45 & 6.36 & 10 & local community & 60.6 \\
\hline & 4 & 4 & 4 & 6 & 6 & 6 & 4 & 4 & 4 & 10 & gender & 52 \\
\hline \multirow[t]{5}{*}{$\begin{array}{l}\text { place } \\
\text { experience }\end{array}$} & 5 & 5 & 5 & 7 & 5 & 5 & 8 & 8 & 5 & 10 & workgroup & 63 \\
\hline & 2.22 & 2.22 & 2.22 & 6.66 & 6.66 & 6.66 & 3.33 & 3.33 & 4.44 & 9 & learning & 46.74 \\
\hline & 2.87 & 2.87 & 2.87 & 4.28 & 5.71 & 5.71 & 4.28 & 4.28 & 2.85 & 10 & leisure & 45.72 \\
\hline & 2.22 & 2.22 & 2.22 & 2.22 & 8.89 & 8.89 & 4.44 & 4.44 & 4.44 & 10 & space geometry & 49.98 \\
\hline & 5 & 5 & 5 & 1 & 6 & 6 & 7 & 7 & 4 & 10 & spatial perception & 56 \\
\hline \multirow[t]{3}{*}{$\begin{array}{l}\text { emotional } \\
\text { significance }\end{array}$} & 6.36 & 6.36 & 6.36 & 2.72 & 3.63 & 3.63 & 3.63 & 3.63 & 3.63 & 8 & own creation & 47.95 \\
\hline & 3.63 & 3.63 & 3.63 & 2.72 & 5.45 & 5.45 & 8.18 & 8.18 & 3.63 & 10 & school of dreams & 54.5 \\
\hline & 5 & 5 & 5 & 2 & 3 & 3 & 3 & 3 & 5 & 10 & space memory & 44 \\
\hline \multirow[t]{2}{*}{$\begin{array}{l}\text { user } \\
\text { imagination }\end{array}$} & 9.09 & 9.09 & 9.09 & 3.63 & 4.54 & 4.54 & 3.63 & 3.63 & 1.81 & 9 & $\begin{array}{l}\text { children form } \\
\text { environment }\end{array}$ & 58.05 \\
\hline & 6 & 6 & 6 & 2 & 4 & 4 & 6 & 6 & 4 & 9 & manipulation & 53 \\
\hline \multirow[t]{2}{*}{$\begin{array}{l}\text { temporal } \\
\text { aspects }\end{array}$} & 2 & 2 & 2 & 4 & 7 & 7 & 4 & 4 & 6 & 9 & ownership & 47 \\
\hline & 3.63 & 3.63 & 3.63 & 6.36 & 5.45 & 5.45 & 6.36 & 6.36 & 4.54 & 10 & users/activities & 55.41 \\
\hline
\end{tabular}

The final results of the survey represented the load distribution, relative importance and relative success of implementation of each of the criteria elements. Figure 07 shows the survey results (highlighted in green), comparing it to assumed load distribution (highlighted in blue), and also comparing to actual results from the participatory workshop in Shagaret el Dorr school (highlighted in red). 
Comparing the red chart to green chart in figure 07 results in better understanding and better evaluation of the process and results of the participatory workshop overall as it highlights the missing or weak steps and also the efficiently implemented participatory criteria elements.

\section{Conclusions}

Design-build participatory approaches process consists of overlapping/sequential steps/phases. These steps provide a range of users' participation guidelines which are recommended to be implemented in different project phases (design - upgrade - maintenance ...etc.) [3]. Each stage provides a detailed guideline and analysis of the impact of using specific recommended guidelines and the holistic reaction of triggering instructions, allowing more accurate strategic decisions to be achieved in later stages depending on the nature and conditions of the project [4].

\section{Summary of Phases}

The first stage: a workshop for team experts and school students

Recommend participatory techniques: personal interview, photo montage and collages, playing ...etc.

Main purpose of this stage: get engaged with target participants, explain the nature and role of each member, and get first round of feedback.

The second stage: academic and school staff participatory sessions

Recommend participatory techniques: personal interview, zoning analysis, drawings, charts, surveys, and observations.

Main purpose of this stage: highlight the main pedagogical spatial needs [5], identify list of priorities and interventions recommendations, and test techniques of teachers' participation [6] in this stage and other stages.

The third stage: conceptual - participatory based design elements generation

Recommend participatory techniques: model making, digital collages, analysis of data gathered from previous stages, defining keywords, defining design proposals.

Fourth stage: Presenting the suggestions of children / students and teachers

Recommend participatory techniques: visual presentation, model making, digital collages, interviews, and surveys.

Main purpose of this stage: collect affiliated parties and participating members' feedback, discuss pros and cons of each alternative, and take collective decisions about the implementation stage.

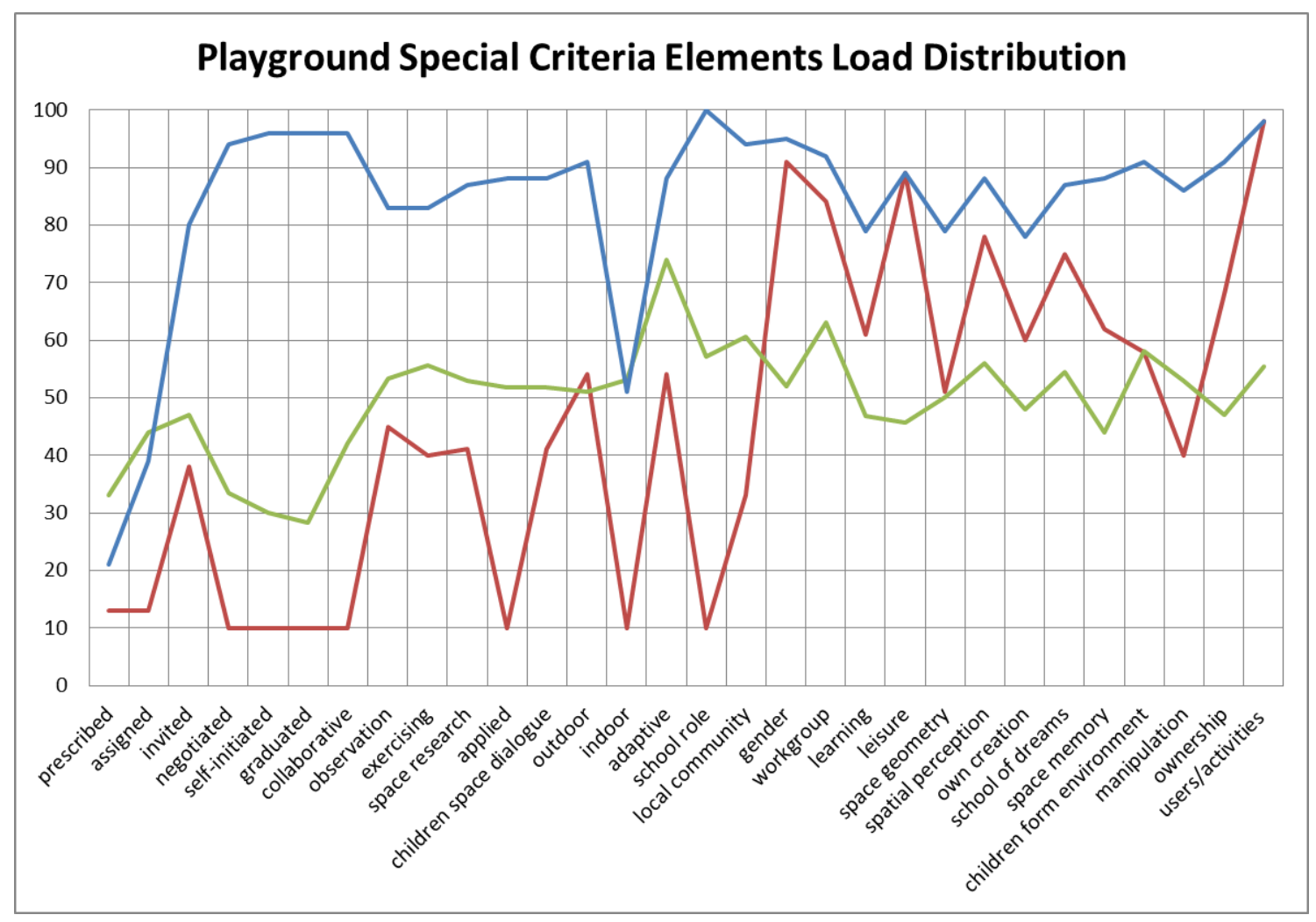

Figure 7. Overall Comparative Special Guideline Criteria Load Distribution with the survey results (highlighted in green), assumed load distribution (highlighted in blue), and actual results (highlighted in red). Author, 2020 


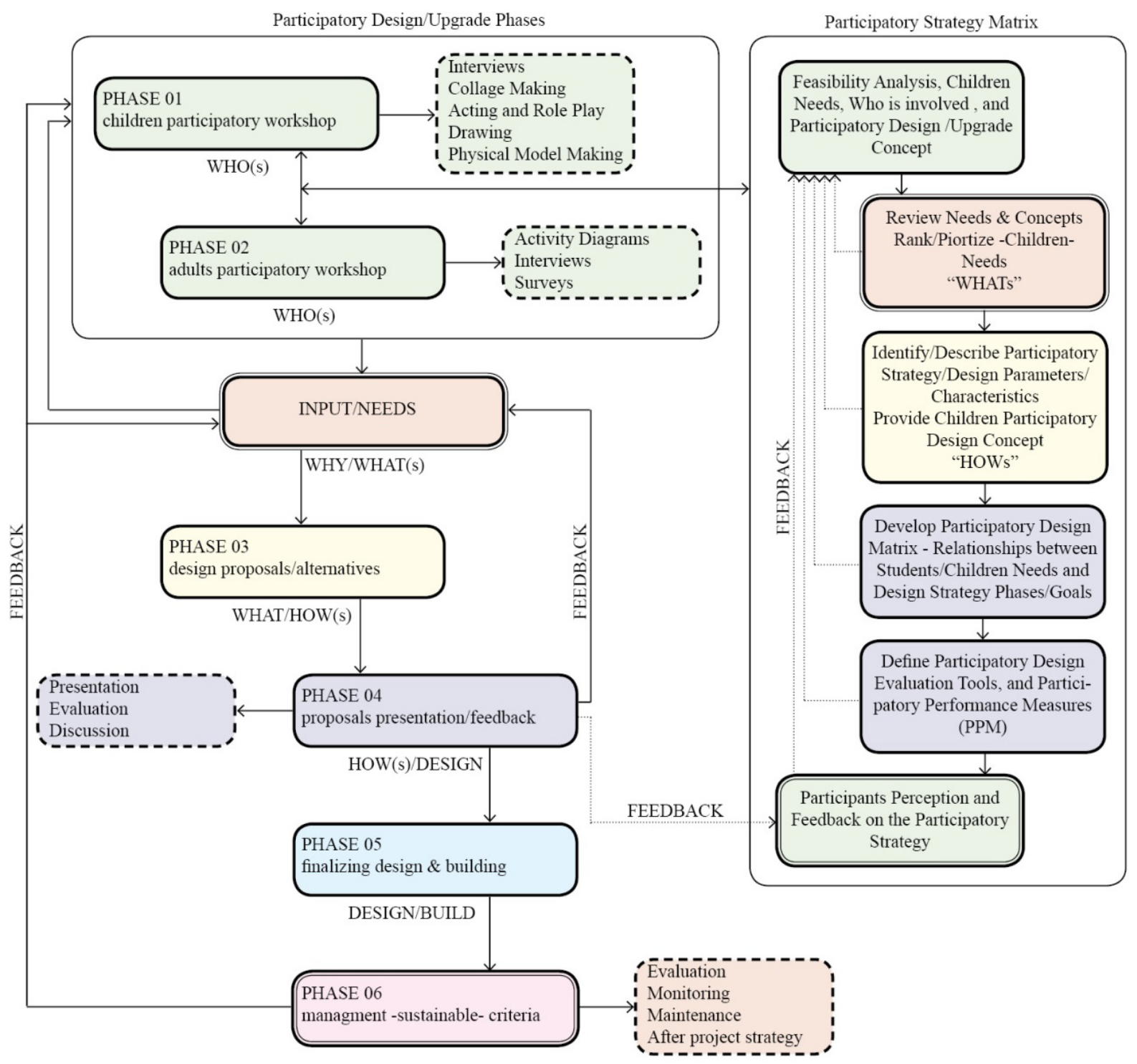

Figure 8. Proposed design-build approach stages breakdown. Author, 2020

\section{Fifth stage: completion of design and construction}

Main purpose of this stage: 2nd round of design proposals development based on input from previous stage, and preparing documents for construction with support of local builders if possible.

Sixth stage: final summary, feedback, and implemented elements observation/evaluation

Main purpose of this stage: establish a long term post-participatory strategy observation and data gathering system [7] to evaluate users' engagement and satisfaction with results for a long term duration.

The previously mentioned stages and standard guidelines change depending on the design strategy goal and project setting. The proposed guidelines are flexible and focus on promoting and developing a participatory design approach with efficient educational environmental built environment quality. The proposed guidelines/stages can also be used as an assessment tool [8] for the efficiency of the implementation of any participatory strategy in a school context.

\section{REFERENCES}

[1] Capresi V., Pampe B. "Learn Move Play Ground - how to improve playgrounds through participation". Jovis, Berlin. 2013. ISBN: 8973868592245

[2] Kawano, N., Muramaki, S., Kawaguchi, K., "Elementary School Planning in Japan: A Historical Study for Regulations," Civil Engineering and Architecture, Vol. 6, No. 5, pp. 234 - 241, 2018. DOI: 10.13189/cea.2018.060502.

[3] Dael, M., Helmer-Petersen, J., Grønbech, P., Rasmussen, P., 
Madsen, M. "Architecture and Design for Children and Youth. The Network for Children and Culture", Copenhagen. 2011. ISBN: 978-87-92681-25-6.

[4] Çağlar, F., Gedik, G., Gökdemir, H. "The Impact of Transparency Ratio on Thermal Comfort: A Field Study on Educational Building", Civil Engineering and Architecture, Vol. 8(5), pp. 890 - 897, 2020. DOI: $10.13189 /$ cea.2020.080516.

[5] Dudek, M. "A Design Manual-Schools and Kindergartens", Basel-Boston-Berlin: Birkhauser. 2007. ISBN: 139783 764370534 .
[6] Sánchez, G., Izaguirre, V. "Habitability, a Basic Premise for Home Design and Its Impact on the Curricula of Architecture Schools". Civil Engineering and Architecture, Vol. 8, No. 5. pp. 950 - 962, 2020. DOI: 10.13189/cea.2020.080522.

[7] Distefano, N., Leonardi, S., Pulvirenti, G. "Home-school Travel: Analysis of Factors Affecting Italian Parents' Mode Choice". Civil Engineering and Architecture, Vol. 7, No. 3. pp. $75-87,2019$. DOI: 10.13189/cea.2019.070302.

[8] Rüller, S., Aal, K. "Interventionistic Participatory Design (IPC)". Tech Otherwise, 2020. DOI: $10.21428 / 93 \mathrm{~b} 2 \mathrm{c} 832.007 \mathrm{f} 3 \mathrm{~d} 63$. 